\title{
THE COMPETITIVE ENVIRONMENT AMONG COMPANIES IN THE CZECH PART OF EUROREGION NEISSE-NISA-NYSA
}

\author{
Jaroslava Dědková, Klára Blažková
}

\section{Introduction}

The competitive environment in the global economy of the 21st century is highly-complex, demanding and full of competitive opportunities and threats. An effective strategy of company management can help companies improve their performance when faced with simultaneous competition in a turbulent and unpredictable environment. Each and every entrepreneur must be aware that his customers and his own business are not alone on the market - he must know his competition. [5]

The Czech economy has also undergone considerable change in the past two decades. The period of transformation from planned economy to market economy and the openingup of the Czech economy are linked to the arrival of new competitors from abroad and even fiercer competition. This has also resulted in a change to the competitive advantage and competitiveness of Czech companies. [18]

When planning business activity, all companies need to be able to forecast future development on the market on which they wish to operate. Knowledge of the environment in which a company operates and information about the competition are the currency of each and every business. Being aware and having an overview of competing companies, their products and prices are essential to preparing sales tactics and putting together a company strategy from the perspective of offering and presenting a company's own products. As with the environment in which the company is active, the competitive environment continues to develop, meaning that continual attention must be paid.

The main aim of the paper is to analyse the strength of the competitive environment, the primary competitive advantages of the companies within ERN and the dependence of the competitive strategies chosen and competitive advantage among the companies active within the Czech part of ERN.

A quantitative form of collecting data, by way of written questionnaire, was chosen as the method of obtaining the information we required, this questionnaire taking the shape of an electronic survey created using the tools available at Google.com. The survey was carried out in January and February 2013 in the Czech part of ERN and was anonymous. The Statgraphics programme was used to process data.

\section{The Terms "Competitive Advantage" and "Competitiveness"}

Defining "competitive advantage" and "competitiveness" can be done from both the macroeconomic and the microeconomic reading of the terms. Nevertheless, both perspectives are connected to each other and it can be said that a company's competitive advantage (microeconomics) influences and predetermines the competitiveness of the whole, meaning the macroeconomic point of view [1]. This is indicated in the microeconomic nature of the term "competitiveness", which defines a competing company as a company that is able to compete with the competition [1] and encapsulates the relative performance of the company in question at the given time. This general concept can be developed and competitiveness defined as a characteristic which allows a business undertaking to be successful when it competes with other business undertakings [5]. Competitive advantage and competitiveness are closely 
related to each other and are in fact relative terms [19]. Any identification of competitive advantage draws on a comparison of a group of companies, in that this comparison is itself dependent on the nature of the market environment in which the company operates.

We cannot talk of a company's competitive advantages without also talking of specific competitive conditions or independent of a specification of rivals. A company might be competitive in relation to several rivals, but uncompetitive to others. [7]

Competitiveness is fundamentally generated through competitive advantages, for which we can accept Porter's concept that as such they offer the company an advantage over its competitors. Competitive advantage can be seen here as a factor that helps or allows a company to achieve success, although it need not guarantee it [11]. There are many levels to the idea of competitive advantage and the competitiveness that arises from it in terms of the concept of a company's success.

The first level is achieving sufficient quality of advantages and competitiveness for the company to be able to compete in the first place. We can understand this achievement of basic limits to be the qualifying level of competitiveness. The next level, "self-realisation", helps the company achieve such success by reaching set targets that do not fundamentally threaten other competitors. In practice, this means that the company pursues its own specific targets, the achievement of which does not restrict competitors in reaching their targets. In this case, companies do not come into direct conflict. The third level is required when it is impossible for a company to accomplish its own targets without affecting the achievement of targets by its competitors in some significant way. [22]

Creating a competitive advantage on the market means achieving two things:

1. Creating something the competitors do not have;

2. Creating something that customers consider to be better than the alternatives (perhaps the products made by direct competitors, something they can make on their own or doing nothing).

Therefore, creating a high and unique value in the eyes of the customers means having a competitive advantage.
A competitive advantage is something extra that a company offers over the competition. Something that makes the company exceptional. It is not easy being the best in your field in this day and age; after all, everyone else is trying to do the same. It is now about details, which the customer uses to decide who to choose and where to buy. Everyone tries to offer the best-quality products they can at the most reasonable prices. It needs to be able to provide every potential customer with an answer to the question, "Why should I buy from them?" Among other, our project was interested in whether companies are aware of their competitive advantage and how they are dependent on the competitive strategy they chose.

Pace offers a different view of competitiveness: one of the primary goals of organizations in a free enterprise systém. Although the measures of competitiveness may appear different for manufacturing and service organizations or for government and religious organizations, in order to be competitive, any organization must provide products and services for which customers or clients are willing to pay a fair return or price. In the long run, in a free enterprise system, competitiveness is measured by the ability of the organization to stay in business and to protect the organization's investments, to earn a return on those investments, and to ensure jobs for the future. [9]

We assume that a competitive advantage is a sort of image in the eyes of customers, employees, suppliers etc. (so-called stakeholders) and is a prerequisite for the economic management of a company. It also stands that if the company is able to compete, it is also highly efficient. In the short-term, we are interested mainly in profitability or market share and in the long-term in the capacity to innovate and grow, company strategy, vision for the future or the use of company potential. [17], [18]

\subsection{Types of Competitive Advantage}

It is universally known that quality, supply (reliability), flexibility and effectiveness of costs are possible competitive advantages. Quality can be defined, through a set of innate properties, as the level of requirement of satisfaction. The quality of a product encompasses the technical 
perspective (production technology and technical standards) and (in particular) the ability to satisfy customer requirements [18]. Customer satisfaction is closely related to other factors, such as loyalty or the value for the customer, which significantly increase the competitive advantage and competitiveness of the company [15]. Many managers believe that all functions of the company need to be improved at the same time in order to improve some of the constituent parts of that company's competitive advantage. [21]

Recent studies, however, affirmatively showed the importance of non-price factors as basic determinants of competitiveness. The scope of non-price factors is diverse. It includes:

- human resources and personnel conditions, such as employee skills and motivation;

- technical factors such as research and development capabilities and the ability to adapt and use technology;

- management and organisational factors, both internal, in relation to the company, and external relations with other bodies (customers, suppliers, public and private research institutes and other companies).

These factors determine the ability of a company to achieve and maintain a profitable position in a changing environment.

According to Porter, there are four mutuallydependent and mutually-reinforcing attributes of competitive advantage that allow companies to successfully compete in a particular field:

- the availability of qualified labour and infrastructure;

- demand for goods and services on the market;

- associated support of industry, including the presence of competing suppliers;

- company strategy, structure and rivalry. [13] Porter describes these factors as those which "individually, and as a system, create the context in which a nation's firms are born and compete". Porter considers that the most important issue of all for competitiveness lies in the pressure that these factors exert on firms to invest and innovate. [2]

Continually improving the range of products or services that a company can offer has become increasingly popular. Continual improvement is based on five pillars:
- the involvement of all company employees at all levels;

- looking for savings without making investment;

- enumerating data and information;

- using common sense as a basic tool;

- implementing ideas from practice. [14]

An increasing number of companies no longer focus on competition and employing the competitive advantage of price, instead concentrating on quality, service and individualising the range of goods or services they offer. To assert themselves on the market, however, companies are also using a competitive strategy based on their experience or specific know-how and the expertise of their workers. Some companies build their success on the reputation of the company or a brand of products. [4] Some companies consider their management of key customers to be a competitive advantage.[11] Companies can achieve considerable competitive advantage by taking into consideration the ethical and environment demands placed on products, price and distribution. Cementing the company's position within the competitive environment, having satisfied customers and achieving better financial results: these are just some of the advantages arising from greater responsibility in a company's marketing behaviour [8], [10].

\subsection{Euroregion Nisa}

More emphasis has been placed on the significance of the region in recent years. This goes hand-in-hand with the recognition that regions are the foundation of national competitiveness; it is at this level that we see the direct clash of those who create knowledge and those who use it. The prosperity of a region, then, depends primarily on how that particular region succeeds in overcoming the potential gulf between these two groups of entities [1].

The second reason for such emphasis having recently been placed on regions is the change in the world economy, which is becoming "regionalised" as multinational groupings. This leads to a certain restriction in the role of nation states, which lose certain opportunities in terms of carrying out macroeconomic policy. It can be said that states have become regions in a way, since their procedures in influencing economic phenomena are more reminiscent of the procedures used by regional authorities. 


\section{Euroregion Neisse - Nisa - Nysa}

Euroregion has been established in 1991. All three parts of the region are united by many common issues and interests arising from similar system transformations and many years of common history. The River Nisa which forms the border between Germany and Poland is unifying element of the area as a whole and the traditional symbol of mutual cooperation.

The Czech part of Euroregion Nisa encompasses Česká Lípa, Jablonec nad Nisou,
Liberec, Semily and the northern part of the Děčín district (around Šluknov) and covers around $4.5 \%$ of the area of the Czech Republic. This part of the Euroregion is home to 135 municipalities (figure taken from 2011). Emphasis is placed on strengthening competitiveness and regional economic bases by way of cooperation, with special consideration for interaction between small and medium-sized businesses and in support of developing new business opportunities. [3]

\section{Tab. 1: Selected indicators for the region}

\begin{tabular}{|c|c|c|c|c|c|c|}
\hline & & Liberec & $\begin{array}{l}\text { Jablonec } \\
\text { nad Nisou }\end{array}$ & Česká Lípa & Semily & Total \\
\hline \multicolumn{2}{|c|}{ Number of undertakings } & 52,239 & 24,391 & 23,847 & 19,431 & \multirow[t]{7}{*}{119,908} \\
\hline \multirow{3}{*}{$\begin{array}{l}\text { By number } \\
\text { of employees }\end{array}$} & $0-9$ & 51,363 & 23,989 & 23,484 & 19,060 & \\
\hline & $10-49$ & 680 & 318 & 278 & 283 & \\
\hline & 50 and over & 196 & 84 & 80 & 88 & \\
\hline \multirow{3}{*}{$\begin{array}{l}\text { By economic } \\
\text { activity }\end{array}$} & agriculture & 1,649 & 647 & 1,031 & 1,264 & \\
\hline & industry & 15,468 & 7,950 & 6,805 & 5,484 & \\
\hline & services & 34,194 & 15,052 & 15,126 & 12,116 & \\
\hline \multicolumn{2}{|c|}{ Rate of unemployment } & $9.9 \%$ & $9.3 \%$ & $11.9 \%$ & $10.0 \%$ & $10.3 \%$ \\
\hline \multicolumn{2}{|l|}{ Population } & 171,007 & 89,987 & 103,037 & 74,563 & 438,594 \\
\hline \multicolumn{2}{|l|}{ GDP } & \multicolumn{2}{|c|}{$\begin{array}{c}\text { CZK 283,671 per one head } \\
\text { of population }\end{array}$} & \multicolumn{2}{|c|}{$\begin{array}{c}\text { CZK } 124,416 \text { million } \\
\text { Total }=3.2 \% \text { of the figure } \\
\text { for the Czech Republic }\end{array}$} & \\
\hline \multicolumn{2}{|c|}{ Average gross monthly pay } & \multicolumn{4}{|c|}{ CZK 22,823 } & \\
\hline
\end{tabular}

Source: [3]

The main industries here are the traditional glass and costume jewellery, the manufacture and processing of plastics, engineering and branches of the processing industry closely linked to car manufacturing. The textile industry has experienced a slump in recent years and has lost its once-prominent position. In terms of the rate of unemployment, the Liberec region is one of the worst-affected areas, having a rate of $10.3 \%$ at 31. 12. 2012.

The economy of the Liberec region is strongly represented by the processing industry. This relates to the long-standing industrial traditions of the region and major recent investment by foreign companies. The share of the processing industry in the creation of gross added value is around $50 \%$ higher than the average for the Czech Republic. The share of construction is also slightly higher, but other significant branches have a lower share in the Liberec region in comparison with the Czech Republic. Somewhat surprising is the higher share of education and the health industry. Small and medium-sized businesses have an important position in the regional economy, employing $65.5 \%$ of the total number of employees in 2012. [6]

The area is characterised by a long-standing tradition of technical know-how and other specific export production, by the existence of a relatively-well qualified workforce in certain industries (particularly engineering and glassmaking) and its competitiveness from the perspective of salary costs and by the development of business activity by foreign investors, primarily in the motor industry and other export industries. 
Systematic support of small and medium-sized business presents an opportunity for this area, as do using the transfer of innovation to increase the competitiveness of all business undertakings, the preparation and development of business zones and technology parks, the development of strategic services and of progressive branches with high added value in cooperation with foreign organisations and companies and the involvement of regional science and research centres and the potential of the Technical University of Liberec. [6]

\section{Results and Analyses}

This section examines and evaluates the quantitative data taken from a questionnaire survey. It is divided into smaller parts, the first characterising the profile of respondents and the second concentrating on a statistical analysis of selected questions relating to the competitive environment. A total of 170 companies from the Czech part of Euroregion Nisa completed the questionnaire.

\subsection{Methodological Procedure of Marketing Survey}

The methodology used in the empirical investigation of the competitive strategies of companies is based on the definitions, expectations and principles set out in the introduction to the paper. A quantitative form of collecting data in a written questionnaire was chosen as the method of obtaining the information we required, this questionnaire taking the shape of an electronic survey created using the tools available at Google.com. The survey was carried out in January and February 2013 in the Czech part of Euroregion Nisa and was anonymous.

A uniform, standardised, structured questionnaire was used to gather data in which the wording and order of questions were precisely set out. Closed-ended, multiple-choice questions were mainly used in the questionnaire, although open-ended questions were employed to ascertain competitive strategies. The Statgraphics programme was used to process data.

Closed-ended, multiple-choice questions were mainly used when putting together the questionnaire. A set of variables that influence the competitiveness of a company was assembled based on the theoretical knowledge available and space was given to respondents to rate these individual variables.

\subsection{Characteristics of the Sample}

For the purposes of considering the economic base, the Czech part of the region was divided into the districts of Liberec, Jablonec nad Nisou, Česká Lípa and Semily. A database was created of 250 companies active in the districts of Euroregion Nisa in question. These companies were contacted by telephone and subsequently sent an electronic link to the questionnaire in the Google.com system. One hundred and seventy questionnaires were subsequently processed.

The opening questions 1 to 5 in the questionnaire were designed to identify the sample of respondents. The first question was used to identify the location of the company within Euroregion Nisa. This spread of companies corresponds to the size of the districts in question.

Core business activities differed greatly and were divided into the categories of industry, services, trade and transport and other to help us process the information. Eighty-nine companies were classified under industry (building, engineering, glassmaking, food production, textile industry), meaning 52\%, 77 were classified under services, trade and transport (45\%) and the rest, almost 3\%, were deemed to be part of another specific industry.

\subsection{Intensity of Competition and Number of Competitors}

A statistical evaluation of the answers we received allows us to better identify the competitive environment and company activity relating to the growing competition within Euroregion Nisa.

As part of the questionnaire survey, companies considered their competitive environment by looking at the intensity of competition and the number of competitors they have. Statistical processing allowed us to look at the possibility of whether there is a relationship between the intensity of competition and the number of competitors. We set out hypothesis 0 , which proves that there is no relationship between the intensity of competition and the number of competitors, and hypothesis 1 , which confirms dependence, and tested these.

$\mathrm{H}_{0}$ : There is no relationship between the intensity of competition and the number of competitors.

$\mathrm{H}_{1}$ : There is a relationship between the intensity of competition and the number of competitors.

Given that this is a categorised variable, a contingency table 1 was chosen for evaluation purposes. 
Tab. 2: Characteristics of the sample

\begin{tabular}{|c|c|c|c|c|c|c|}
\hline & Liberec & $\begin{array}{l}\text { Jablonec } \\
\text { nad Nisou }\end{array}$ & Česká Lípa & Semily & & \\
\hline Location of company & $53 \%$ & $14 \%$ & $13 \%$ & $20 \%$ & & \\
\hline Legal form of business undertaking & $\begin{array}{c}\text { joint stock } \\
\text { company } \\
29 \% \\
\end{array}$ & $\begin{array}{c}\text { limited liability } \\
\text { company } \\
61 \%\end{array}$ & $\begin{array}{c}\text { state } \\
\text { enterprise } \\
4 \% \\
\end{array}$ & $\begin{array}{c}\text { cooperative } \\
1 \% \\
\end{array}$ & \multicolumn{2}{|c|}{$\begin{array}{c}\text { natural person } \\
5 \% \\
\end{array}$} \\
\hline Number of employees & $\begin{array}{c}\text { Less than } 10 \\
14 \%\end{array}$ & $\begin{array}{c}11-20 \\
11 \%\end{array}$ & $\begin{array}{c}21-50 \\
11 \%\end{array}$ & $\begin{array}{c}51-100 \\
24 \%\end{array}$ & $\begin{array}{c}101-200 \\
14 \%\end{array}$ & $\begin{array}{c}\text { More } \\
\text { than } \\
200 \\
27 \%\end{array}$ \\
\hline Business activity & $\begin{array}{c}\text { Industry } \\
52 \%\end{array}$ & $\begin{array}{c}\text { Services } \\
45 \%\end{array}$ & $\begin{array}{l}\text { Other } \\
3 \%\end{array}$ & & & \\
\hline Foreign capital & $\begin{array}{c}\text { Up to } 25 \% \\
2.4 \%\end{array}$ & $\begin{array}{c}26-50 \% \\
5.3 \%\end{array}$ & $\begin{array}{c}51-75 \% \\
6.5 \%\end{array}$ & $\begin{array}{c}\text { Over } 75 \% \\
16 \%\end{array}$ & $\begin{array}{r}\text { No for } \\
\text { capi } \\
69.8\end{array}$ & $\begin{array}{l}\text { eign } \\
\text { tal } \\
\%\end{array}$ \\
\hline
\end{tabular}

Source: compiled by the authors

\section{Tab. 3: Contingency table of dependence of intensity of competition on number of competitors}

\begin{tabular}{l|c|c|c|c} 
& Strong & Weak & Medium & Row total \\
\hline 0 competitors & 0 & 6 & 0 & 6 \\
\hline 1 competitor & $0.00 \%$ & $3.53 \%$ & $0.00 \%$ & $3.53 \%$ \\
\hline & 0 & 4 & 4 & 8 \\
\hline $2-5$ competitors & $0.00 \%$ & $2.35 \%$ & $2.35 \%$ & $4.71 \%$ \\
\hline & 13 & 2 & 50 & 65 \\
\hline 5 or more competitors & $7.65 \%$ & $1.18 \%$ & $29.41 \%$ & $38.24 \%$ \\
\hline & 75 & 0 & 16 & 91 \\
\hline Column total & $44.12 \%$ & $0.00 \%$ & $9.41 \%$ & $53.53 \%$ \\
\hline & 88 & 12 & 70 & 170 \\
\hline
\end{tabular}

Source: compiled by the authors

We can say that the $\mathrm{H}_{0}$ hypothesis, at a significance level of $5 \%$, can be rejected. The indicators of the descriptive statistic allow us to say that the intensity of competition is dependent on the number of competitors. The intensity of dependence is substantiated by the value of the contingency coefficient -0.7109 , representing medium dependence. Pearson's moment correlation coefficient reaches a value of 0.58 ( $p$-value $<0.01$ ).

\subsection{Improving Competitive Position on the Market}

Another question focusing on the issue of the competitiveness of companies is to identify whether they involve themselves in trying to move ahead of the competition, either through their own activities or with the help of a consultant. 


\section{Fig. 1: The intensity of competition}

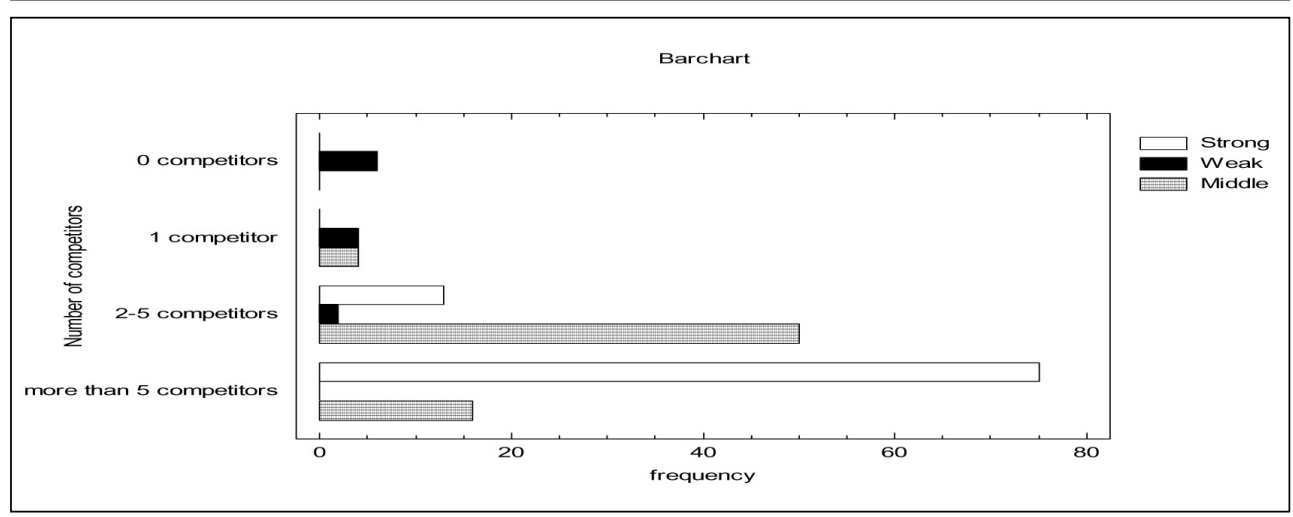

Source: own

\section{Tab. 4: Engaging the competition - the company itself}

\begin{tabular}{c|l|c|c|c|c} 
Class & Value & Frequency & $\begin{array}{c}\text { Relative } \\
\text { Frequency }\end{array}$ & $\begin{array}{c}\text { Cumulative } \\
\text { Frequency }\end{array}$ & $\begin{array}{c}\text { Cumulative Relative } \\
\text { Frequency }\end{array}$ \\
\hline 1 & yes & 93 & 0.5471 & 93 & 0.5471 \\
\hline 2 & no & 16 & 0.0941 & 109 & 0.6412 \\
\hline 3 & sometimes & 24 & 0.1412 & 133 & 0.7824 \\
\hline 4 & probably & 37 & 0.2176 & 170 & 1.0000 \\
\hline
\end{tabular}

It is evident from the table 4 above that 93 of the 170 companies systematically engage in trying to move ahead of the competition. The largest sector is the engineering industry, with $20.43 \%$, followed by services - other and services - commerce with $13.97 \%$ each. By contrast, only 16 companies do not engage in this issue themselves.

\subsection{The Competitive Advantage of a Company}

According to Michael E. Porter [12], competitive advantage is at the heart of the efficiency of a business entity on a market with established competition. It stems from the value which the entity is able to offer its customers and which exceeds the costs of its creation.

The question figured in the questionnaire survey as an open-ended question and companies therefore had the opportunity to express in full the elements behind their competitive advantage. Given that open-ended questions are harder to evaluate from the statistical perspective, answers had to be coded and assigned to the following categories: low price, quality, reliability, strong brand, service, tradition, know-how and other.

Companies most often see their competitive advantage as being the service they provide. Twenty-eight per cent of respondents, in fact, replied as such (Fig. 2). The second most commonly-used competitive advantage was the quality of the company's products or services and in third place low price. By contrast, least companies consider tradition and reliability to be competitive advantages. 


\section{Fig. 2: Competitive advantage}

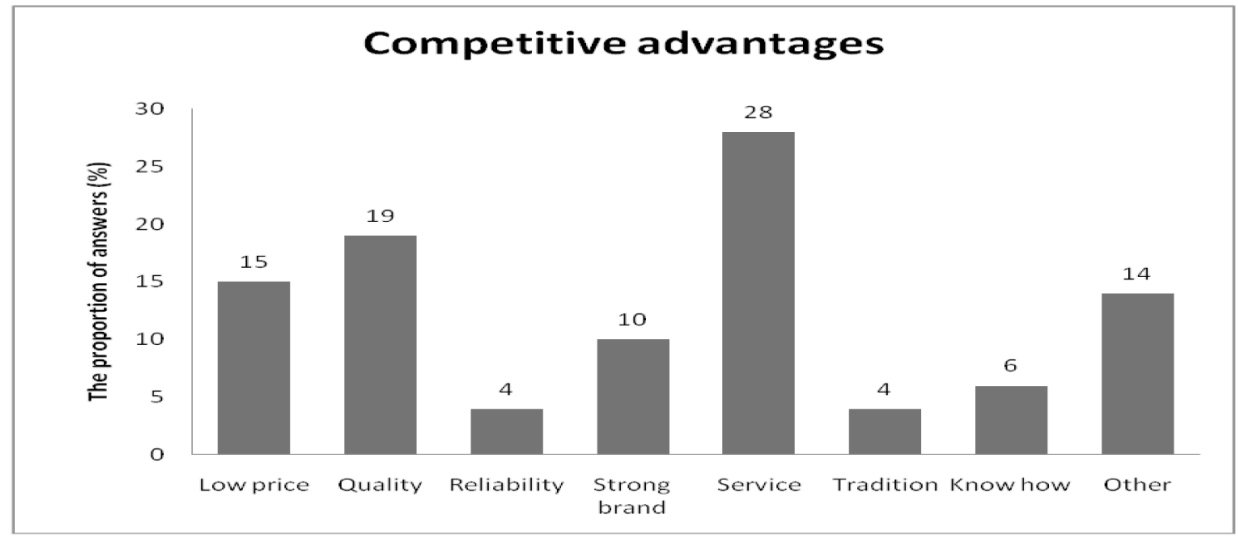

Source: compiled by the authors

A company's membership of a commercial association might also be seen as a possible competitive advantage. The Chamber of Commerce of the Czech Republic, which represents the commercial public, is one example of a commercial association or federation. This organisation supports all areas of business apart from agriculture, the food industry and forestry, these interests being represented by the Agrarian Chamber of the Czech Republic. The main aim of the chamber is to create opportunities for business and to push through and support measures that contribute to the development of business in the Czech Republic and in turn to the overall economic stability of the state.

Although nobody specifically mentioned this as a competitive advantage, our findings do suggest the relationship of this connection. The independence test was used again when considering the relationship between membership of a commercial association and competitive advantage.

\section{Tab. 5: Test of independence}

\begin{tabular}{l|c|c|c} 
& \multicolumn{2}{|c|}{ Competitive advantage } & \\
\hline Membership of a commercial association & yes & no & Row total \\
\hline yes & 22 & 38 & 60 \\
\hline no & $20.18 \%$ & $34.86 \%$ & $55.05 \%$ \\
\hline Column total & 2 & 47 & 49 \\
\hline & $1.83 \%$ & $43.12 \%$ & $44.95 \%$ \\
\hline
\end{tabular}

Source: compiled by the authors 
It emerges from the tested values and results (table 5) that there is a relationship between membership of a commercial association and a competitive advantage from membership. The degree of dependence can be shown in a contingency coefficient, whose value of 0.3643 makes it a medium dependence. Pearson's coefficient came out at 0.39 ( $p$-value < 0.01). From the obtained results it is evident that the membership of the commercial association (not only in the Chamber of Commerce) can provide a competitive advantage to the enterprise.

\subsection{The Rrelationship between Chosen Strategy and Competitive Advantage}

This evaluation considers the relationship between the strategy chosen by companies and their competitive advantage. The coding of answers to concern competitive advantage was extended to 10 variables for a more precise identification of dependence. The strategies used by companies were then represented by the following variables: price strategy, innovation strategy, strategy with emphasis on service, strategy with emphasis on quality and other strategies. Hypothesis 0 disproved any relationship between chosen strategy and competitive advantage, whereas hypothesis 1 proved it.

$\mathrm{H}_{0}$ : No relationship between chosen strategy and competitive advantage.

$\mathrm{H}_{1}$ : Relationship between chosen strategy and competitive advantage.

\section{Tab. 6: The relationship between competitive strategy and competitive advantage}

\begin{tabular}{l|c|c|c|c|c} 
Competitive advantage & $\begin{array}{c}\text { Price } \\
\text { strategy }\end{array}$ & $\begin{array}{c}\text { Innovation } \\
\text { strategy }\end{array}$ & Other & $\begin{array}{c}\text { Strategy with } \\
\text { emphasis on } \\
\text { service }\end{array}$ & $\begin{array}{c}\text { Strategy } \\
\text { with emphasis } \\
\text { on quality }\end{array}$ \\
\hline Other & 7 & 4 & 5 & 3 & 0 \\
\hline Know-how & $4.40 \%$ & $2.11 \%$ & $3.14 \%$ & $1.89 \%$ & $0.00 \%$ \\
\hline & 2 & 7 & 0 & 0 & 0 \\
\hline Quality & $1.26 \%$ & $4.40 \%$ & $0.00 \%$ & $0.00 \%$ & $0.00 \%$ \\
\hline Marketing & 7 & 3 & 1 & 8 & 0 \\
\hline Don't know & $4.40 \%$ & $1.89 \%$ & $0.63 \%$ & $5.03 \%$ & $0.00 \%$ \\
\hline & 3 & 0 & 1 & 0 & 0 \\
\hline Low price & $1.89 \%$ & $0.00 \%$ & $0.63 \%$ & $0.00 \%$ & $0.00 \%$ \\
\hline & 3 & 0 & 0 & 1 & 0 \\
\hline Service & $1.89 \%$ & $0.00 \%$ & $0.00 \%$ & $0.63 \%$ & $0.00 \%$ \\
\hline & 19 & 0 & 0 & 4 & 0 \\
\hline Strong brand & $10.69 \%$ & $0.00 \%$ & $0.00 \%$ & $2.52 \%$ & $0.00 \%$ \\
\hline & 11 & 2 & 3 & 5 & 1 \\
\hline Reliability & $6.92 \%$ & $1.26 \%$ & $1.89 \%$ & $3.14 \%$ & $0.63 \%$ \\
\hline & 6 & 0 & 0 & 2 & 0 \\
\hline Tradition & $3.77 \%$ & $0.00 \%$ & $0.00 \%$ & $1.26 \%$ & $0.00 \%$ \\
\hline & 0 & 0 & 0 & 0 & 0 \\
\hline Column total & $0.00 \%$ & $0.00 \%$ & $0.00 \%$ & $0.00 \%$ & $0.00 \%$ \\
\hline & 4 & 0 & 0 & 3 & 0 \\
\hline & $2.52 \%$ & $0.00 \%$ & $0.00 \%$ & $1.89 \%$ & $0.00 \%$ \\
\hline & 62 & 16 & 10 & 26 & 1 \\
\hline & $37.74 \%$ & $7.55 \%$ & $6.29 \%$ & $16.35 \%$ & $0.63 \%$ \\
\hline
\end{tabular}


The statistical values calculated allow us to reject $\mathrm{H}_{0}$ and accept $\mathrm{H}_{1}$. The intensity of dependence is given by the contingency coefficient of 0.6874 , which is medium. The chosen strategy depends on the competitive advantage which a company has on the market over its competitors.

\subsection{The Manner of Competition and Reaction to Competition}

The companies were able to judge the way in which competition is manifested most often.
They considered the increase in competition, the wider range of goods the competition has, the lower prices offered by the competition, the wider range of services offered by the competition, the use of more advertising and greater emphasis on winning customers and satisfying them. The results are presented in table 7.

A modal value equalling lower prices was calculated using the Statgraphics programme. The degree of mutability was then calculated by hand.

\section{Tab. 7: Frequencies for expressions of competition}

\begin{tabular}{c|l|c|c|c|c} 
Class & Value & Frequency & $\begin{array}{c}\text { Relative } \\
\text { Frequency }\end{array}$ & $\begin{array}{c}\text { Cumulative } \\
\text { Frequency }\end{array}$ & $\begin{array}{c}\text { Cum. Rel. } \\
\text { Frequency }\end{array}$ \\
\hline 1 & The increase in competition & 60 & 0.1987 & 60 & 0.1987 \\
\hline 2 & Greater selection of products & 30 & 0.0993 & 90 & 0.2980 \\
\hline 3 & Lower prices & 86 & 0.2848 & 176 & 0.5828 \\
\hline 4 & Greater range of services & 29 & 0.0960 & 205 & 0.6788 \\
\hline 5 & More advertisement & 53 & 0.1755 & 258 & 0.8543 \\
\hline 6 & Greater emphasis on customer satisfaction & 44 & 0.1457 & 302 & 1.0000 \\
\hline
\end{tabular}

Source: own

$$
M=\frac{n^{2}-\sum n_{i}^{2}}{n(n-1)}=\frac{302^{2}-17,482}{302+301}=0.811,
$$

in which $\mathrm{M}$ is the number of differences in \% and $n$ is the frequency of answers.

With the highest frequency of 86 , "lower prices offered by competitors" is therefore the modal value of the most common battle. The variability of opinion on frequent or very frequent competition is rather higher at $81.1 \%$.
The companies also judged the most common reactions to competition. They chose between a larger range of goods on offer, the introduction (expansion) of services, the reduction of prices, the introduction or intensification of advertising, increasing efforts to ensure a satisfied customer and zero reaction. The results in table 8 and in figure 3 show that the most common response to competition is to better satisfy the customer.

\section{Tab. 8: Response to competition}

\begin{tabular}{c|l|c|c|c|c} 
Class & Value & Frequency & $\begin{array}{c}\text { Relative } \\
\text { Frequency }\end{array}$ & $\begin{array}{c}\text { Cumulative } \\
\text { Frequency }\end{array}$ & $\begin{array}{c}\text { Cum. Rel. } \\
\text { Frequency }\end{array}$ \\
\hline 1 & Greater range of goods & 61 & 0.1548 & 61 & 0.1548 \\
\hline 2 & Better service & 86 & 0.2183 & 147 & 0.3731 \\
\hline 3 & Price reduction & 72 & 0.1827 & 219 & 0.5558 \\
\hline 4 & Advertising & 41 & 0.1041 & 260 & 0.6599 \\
\hline 5 & Customer satisfaction & 113 & 0.2868 & 373 & 0.9467 \\
\hline 6 & No reaction & 21 & 0.0533 & 394 & 1.0000 \\
\hline
\end{tabular}




\section{Fig. 3: Response to competition}

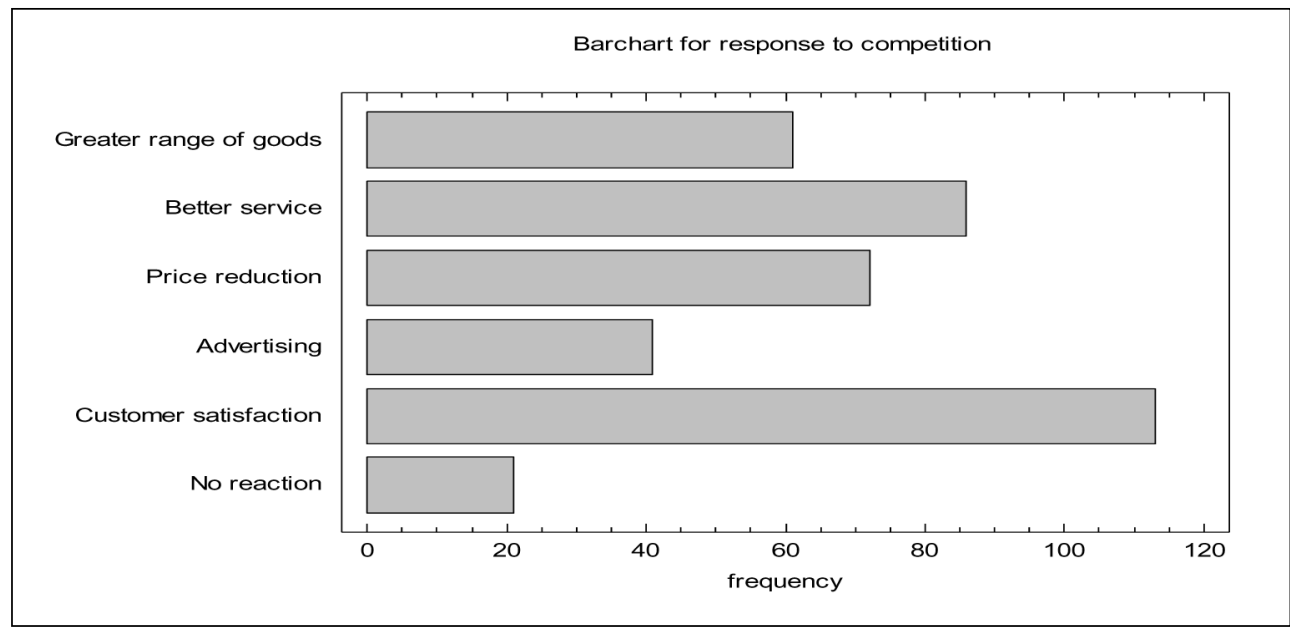

Source: own

A modal value equalling the increase in efforts to satisfy customers was calculated using the Statgraphics programme. The degree of mutability was then calculated by hand.

$$
M=\frac{n^{2}-\Sigma n_{i}^{2}}{n(n-1)}=\frac{3942-31,192}{394+393}=0.801,
$$

in which $M$ is the number of differences in \% and $n$ is the frequency of answers.

The modal value with the highest frequency, 113 , is for "increasing efforts to satisfy the customer". The variability of opinion on a frequent to very frequent response to competition is rather higher at $80.1 \%$.

\section{Discussion}

It ensued from the questionnaire that the competitive environment is very strong in the region throughout the sectors. Over $50 \%$ of respondents characterise their competitive environment as very strong and $40 \%$ as medium. Some $53.3 \%$ of respondents come up against more than 5 competitors. The most common competitive advantages cited by respondents were providing service $(28 \%)$ and the quality of their products (19\%). A detailed investigation confirmed that competitive advantage and competitive strategies need to be understood as multi-dimensional and multifactored because companies always presented more than one factor in competitive advantage. Neither should we forget the communication undertaken by companies, which must be adapted to suit customers, for example in the social media environment. If companies manage their communication in the way defined, there is a high probability that they will defeat the competition in this progressive channel of communication [20]. Effective use of Internet technology offers many possibilities and advantages for both, companies and their customers. Internet used in communication, marketing activities and sales enables cost reduction and high supply chain effectiveness. It represents a major source of competitive advantage, market penetration and innovation [16]. It emerged from our statistical processing that there is a relationship between the competitive strategy chosen and competitive advantages too.

\section{Conclusion}

As presented in the paper, sustainable competitive advantage is one of the deciding factors in the competitive capabilities of business activities at all companies. Competitiveness has become a term that cannot be avoided. It is used by economists, businessmen and politicians. The reason it is used so often could be the fact that it is a word that cannot be replaced. The over- 
generality of the expression means that it can be used at several reference levels, at which the meaning often differs, entirely logically.

Whereas competitiveness is reminiscent of effectiveness statically-speaking, dynamically it is very close to economic growth or to flexibility.

The central point that is forgotten when using the term competitiveness is its relativity. This can logically be understood through the causality explained in the section on competitive advantage. There is, after all, a fundamental difference between competitive characteristics and competitive advantage. Competitiveness is thus a reflection of competitive advantages, which are determined by the specific market situation. That is why it is entirely pointless to use the words competitiveness and competitive without specifying them to take into account the specific circumstances involved, based on the actors in the market process and the market environment itself.

Competitiveness can be identified with prosperity, regardless of its relation to the competition. A company which is not competitive does not have a very good chance of long-term survival. There is no theoretical justification for something like this being true.

Research will continue by examining how competitiveness is perceived in relation to the German and Polish parts of the Euroregion Nisa (ERN). We will also consider the competitive environment for companies who wish to undertake business on the German and Polish sides.

This article was written with financial support for a specific research project under TUL Student Grant Submission No. 38001/2013: Identification of factors of competitiveness among companies in the Czech part of Euroregion Neisse-Nisa-Nysa.

\section{References}

[1] BENEŠ, M. Konkurenceschopnost a konkurenční výhoda [online]. Centrum výzkumu české konkurenceschopnosti. Working Paper No. 5/2006 [cit. 2013-08-16]. 39 p. (PDF). Available from: http://is.muni.cz/do/econ/soubory/oddeleni/centru m/papers/wp2006-05.pdf. ISSN 1801-4496.

[2] CLARK, J., GUY, K. Innovation and competitiveness: A review. Technology Analysis \& Strategic Management. 1998, Vol. 10, Iss. 3, pp. 363-395. ISSN 0953-7325.
[3] Euroregion bez hranic [online]. Liberec: Český statistický úraad, Krajská správa Čsú v Liberci, c2014 [cit. 2014-02-15]. Available from: http://www.czso.cz/xl/ redakce.nsf/i/140206_zsuern.

[4] HOMMEROVÁ, D., KRÁLOVÁ, L. Analýza podpor marketingové činnosti využívaných firmami $\checkmark$ České republice. E+M Ekonomie a Management. 2009, Vol. 12, Iss. 3, pp. 77-90. ISSN 12123609.

[5] IRELAND, R., HITT, M. Achieving and maintaining strategic competitiveness in the 21st century: The role of strategic leadership. The Academy of Management Executive. 1999, Vol. 13, Iss. 1, pp.43-57. ISSN 1079-5545.

[6] KADLAS, Z., RÓLC, R. Analýza socioekonomického rozvoje Libereckého kraje se specifikací potreb po roce 2013 z hlediska kohezní politiky [online]. Agentura regionálního rozvoje, c2010 [cit. 2014-02-02]. 38 p. (PDF). Avaible from: http://www.strukturalni-fondy.cz/getmedia/ ca8be48d-b7a6-4f2f-8b5c-ebc195598ed5/ Analyza-SE-rozvoje-Liberecky_loga.pdf.

[7] METCALFE, J.S., RAMLOGAN, R., UYARRA, E. Economic Development and the Competitive Process. Manchester Centre on Regulation and Competition. Working Paper Series. 2002, No. 36. 31 p. Available also form: http://www.sinal. redesist.ie.ufrj.br/globelics/pdfs/GLOBELICS_0069 _Metcalfeetalli.pdf.

[8] MUSOVÁ, Z. Spoločenská zodpovednost' $\checkmark$ marketingovej praxi podnikov. Banská Bystrica: Univerzita Mateja Bela, Ekonomická fakulta, 2013. 228 s. ISBN 978-80-557-0516-3.

[9] PACE, R., STEPHAN, E. Paradigms of competitiveness. Competitiveness Review. 1996, Vol. 6, Iss. 1, pp. 8-13. ISSN 1059-5422.

[10] PLCHOVÁ, J. Alternatívne prístupy k manažmentu podniku. In Aktuálne otázky ekonomických a humanitných vied '10. Actual Questions of Economic and Human Sciences '10: Zborník príspevkov $\mathrm{z}$ interdisciplinárneho vedeckého kolokvia. Bratislava, 17. december 2010, SR. 1. vyd. Bratislava: STU v Bratislave, 2011. pp. 309314. ISBN 978-80-227-3447-9.

[11] POLIAČIKOVÁ, E. Manažment kPúčových zákazníkov. 1. vyd. Bratislava: IURA Edition, 2012. 101 p. ISBN 978-80-8078-451-5.

[12] PORTER, M.E. Konkurenční výhoda. Praha: Victoria Publishing, 1993. 626 p. ISBN 80-85605-12-0. [13] PORTER, M.E. Konkurenční strategie. Praha: Victoria Publishing, 1994. 403 p. ISBN 80-85605-11-2. [14] PRADO, J. Increasing competitiveness with continuous improvement. Industrial Management. 


\section{Ekonomika a management}

1997, Vol. 39, Iss. 4, pp. 25-27. ISSN 0019-8471. [15] PŮlPÁNOVÁ, L., SIMOVÁ, J. Faktory spokojenosti zákazníků $\mathrm{v}$ cestovním ruchu. E+M Ekonomie a Management. 2012, Vol. 15, Iss. 4, pp. 160-169. ISSN 1212-3609.

[16] SIMOVÁ, J. Customers' online shopping attitudes in relation to their online shopping experience. In KOCOUREK, A. (ed.). Liberec Economic Forum 2013: Proceedings of the 11th International Conference: 16th - 17th September 2013, Sychrov, Czech Republic, EU. pp. 495-503. ISBN 978-80-7372-953-0.

[17] SUCHÁNEK, P., ŠPALEK, J. Competitiveness of Companies in the Czech Republic. The Business Review. 2008, Vol. 11, Iss. 2, pp. 192-199. ISSN 1553-5827.

[18] SUCHÁNEK, P., ŠPALEK, J., SEDLÁČEK, M. Competitiveness Factors in Post-transformation Period: The Case of Czech Enterprises. European Research Studies Jornal. 2011, Vol. 14, Iss. 1, pp. 119-143. ISSN 1108-2976.

[19] SZENTES, T. Interpretations, Aspects and Levels, Decisive Factors and Measuring Methods of Competitiveness. Society and Economy. 2005, Vol. 27, Iss. 1, pp. 5-41. ISSN 1588-9726.

[20] UNGERMAN, O., MYSLIVCOVÁ, S. Identification of Factors which Influence Satisfaction with
Corporate Communication Delivered through Social Media. International Conference on Management, Leadership and Governance. 1st ed. Bangkok University, Thailand, 2013. pp. 400-407. Available also from: http://issuu.com/acpil/docs/ icmlg-13-proceedings.3. ISSN 2049-6826.

[21] VOKURKA, R., DAVIS, R. Improving manufacturing competitiveness: A case study. Competitiveness Review. 1996, Vol. 6, Iss. 1, pp. 68-77. ISSN 1059-5422.

[22] ZICH, R. Koncepce úspěchuschopnosti a její pojetí strategie. E+M Ekonomie a Management. 2010, Vol. 13, Iss. 1, pp. 60-75. ISSN 1212-3609.

PhDr. Ing. Jaroslava Dědková, Ph.D. Technical University of Liberec Faculty of Economics Department of Marketing and Trade jaroslava.dedkova@tul.cz

Bc. Klára Blažková Technical University of Liberec Faculty of Economics Department of Marketing and Trade klara.blazkova@tul.cz 


\section{Abstract}

\section{THE COMPETITIVE ENVIRONMENT AMONG COMPANIES IN THE CZECH PART OF EUROREGION NEISSE-NISA-NYSA}

\section{Jaroslava Dědková, Klára Blažková}

The paper concentrates on the characteristics of the competitive environment in the Czech part of Euroregion Nisa and a constituent part of the outcome of a specific research project at the Faculty of Economics at the Technical University in Liberec.

It can be assumed that a company that wants to succeed on the market must use its competitive advantage and develop its competitiveness. This is based on the ability to respond quickly and correctly to the requirements of customers and competing companies. Competitiveness means a company generating competitive advantages faster than its competitors.

The authors look at the question of which competitive advantages exist among the companies in ERN, what is important to companies and what relationship there is between competitive advantages and the competitive strategies used.

The introduction to the paper presents methodological approaches to the topics of competitive strategies and the competitive environment from the perspective of experts on the matter. The main aim of the paper is to identify and characterise the competitive environment of companies in the Czech part of Euroregion Nisa based on an evaluation of data from primary questioning. The authors of the paper deal with the issue of the main competitive strategies that companies now use and in what lies their competitive advantage. Results and discussion are found in an evaluation of primary research undertaken among 170 companies in the Czech part of Euroregion Nisa. A detailed investigation confirmed that competitive advantage and competitive strategies need to be understood as multi-dimensional and multi-factored. There are several "key" types of competitive advantage, their number and order of importance depending on many circumstances; for example a company's sphere of activity, the area of business activity, the size of the company, the requirements of owners and customers, the priorities of management and so on. Each industry uses its own competitive advantage differently and the decisive factor is succeeding with customers.

It can be contended that successful companies need to produce differentiated products at low cost and need to be flexible.

Key Words: Competitiveness, survey, competitive advantage, competitive strategy.

JEL Classification: M31.

DOI: 10.15240/tul/001/2014-3-008 